\title{
Promoting responsible service policy: The impact of complaint invitation on perceived service recovery performance
}

\author{
Phimai Nuansi \\ Piya Ngamcharoenmongkol \\ NIDA Business School \\ National Institute of Development Administration, Thailand
}

\section{Keywords}

Customer complaint, customer satisfaction, perceived justice, service recovery, sustainable business, sustainable development goals

\begin{abstract}
Given that developing effective, accountable and transparent institutions are the targets of sustainable development goals (SDGs), a shift toward more responsible actions are required for service providers. The present study attempts to establish the role of complaint invitation as the service providers' responsibilities on the advancement of customer complaint handling performance. A scenario-based experiment was carried out in a retail banking service setting. Two types of the service providers' response to service failure (invited complaint vs. customer-self complaint) are compared in terms of customer perceived justice and satisfaction of service recovery. Results from multivariate analysis of variance (MANOVA) suggest that inviting customer to complain can result in higher perceived justice and satisfaction than when the complaint is raised by the customer. Furthermore, invited complaint has a greater impact on perceived interactional justice and satisfaction for customers with low coping potential. This study suggests that understanding the role of service provider's accountability, service managers can more effectively develop and execute customer complaint management policy which contributes to business sustainability.
\end{abstract}

Corresponding author: Phimai Nuansi

Email addresses for the corresponding author: phimai.nua@stu.nida.ac.th

First submission received: 28 th February 2019

Revised submission received: $5^{\text {th }}$ April 2019

Accepted: 20th April 2019

\section{Introduction}

Sustainability management has become a global challenge for organizations worldwide. The Sustainable Development Goals (SDGs) promoted by The United Nations in September 2015 are the blueprint to transform the world to a more sustainable future (United Nations, 2015). SDGs encompass 17 goals with 169 associated targets in achieving the sustainable future for all. Sustainability achievement requires all stakeholders' engagement and collaboration. This brought about the change in the business organization's goals which are redirected from business profit to sustainability (Rakic and Rakic, 2015).

The present study is involved with the SDGs' Goal 16, "promote peaceful and inclusive societies for sustainable development, provide access to justice for all and build effective, accountable, and inclusive institutions at all levels". More specifically, it centers on the specific targets of Goal 16 to develop effective, accountable and transparent institutions at all levels. By the indicator, this target is assessed by the proportion of the population satisfied with their last experience of public services (United Nations, 2015).

In engaging the business organization's practice to this target of the SDGs, this study takes into account the concept of sustainability marketing. As defined by Belz (2006), sustainability marketing involves "building and maintaining sustainable relationships with customers, the social environment and the natural environment". Accordingly, this study focuses on maintaining the sustainable relationships with customer by fostering the firms' responsible actions to enhance consumer service experiences which are leading to more perception of justice and satisfaction in service failure context.

Maxham III (2001) suggested that service failure is the real or perceived problem that customer experiences during a service encounter. Since service delivery involves number of factors such as the employees, customers, service system, and environment, service provider cannot entirely avoid the 
presence of service failure (Berry, 2016). A substantial amount of research on service failure suggests that the poor service experiences are the of cause of negative customer perceptions and behaviours toward service providers, such as, negative attitudes (Kumar et al., 2010), negative word-of-mouth and nonrepurchase (Levesque and McDougall, 1996; McCollough, Berry and Yadav, 2000) which can jeopardize the business sustainability.

Considerable research has shown that an effective service recovery can restore the positive customer perceptions and behaviour after service failure. The extant service recovery literature has recognized customer complaint (Singh, 1988) as an essential input for successful service recovery (Kim, Wang and Mattila, 2010; Ro and Mattila, 2015). However, the dependence on the customer complaint has become the limitations of service recovery implementation because up to $90 \%$ of customers experienced service failure do not complain to the service provider (Tax and Brown, 2012). This leaves massive service failure unresolved and permits the consumers to remain dissatisfied with the poor service experiences thus blocking the business sustainability as discussed earlier.

To address this issue, the current study attempts to explore the beneficial effects of promoting the responsible actions of service provider on customer perceived service recovery efforts. While the literature has well documented customer responses to service recovery based on customer-self complaint, no study has explored how customers would respond to service recovery if they were invited to complain and that complaint leads to service recovery. Building upon complaint handling concept, this research proposes a new construct, namely, complaint invitation, as a firms' responsible action to service failure. The current research thus investigates how different conditions of customer complaint affect customer evaluations of service recovery.

In service recovery context, customers evaluate company's complaint handling performance through an evaluation of justice perception and customer satisfaction (e.g., Chen and Lee, 2018; Tektas, 2017; Yilmaz, Ari and Gürbüz, 2018). As customers perceive their ability to deal with service failure differently, justice perception and satisfaction with complaint handling may be different across complaint situations and perceived capability to cope with service failure. Specifically, this study examines the main effect of complaint situation and the effect of interaction between complaint situation and coping potential on perceived justice and customer satisfaction.

This paper first provides the literature review of service failure and service recovery, customer complaint, and then introduces the concept of complaint-invitation. This is followed by the literature review of service recovery, perceived justice, customer satisfaction, and coping potential. The next section depicts the hypothesis development. The description of research methodology, analysis, and results are provided. The final section discusses research and managerial implications, limitations of the study, and future research avenues.

\section{Literature review}

\subsection{Service failure and service recovery}

Zero defect is not possible in-service provisions (Hart, Heskett and Sasser Jr, 1989). The occurrence of the defect, known as service failure, is a deterioration of the firm-customer relationship. The research indicated that service failure causes a range of customer negative experiences, such as, negative emotions, complaint, negative word-of-mouth, and exit (e.g., Kalamas, Laroche and Makdessian, 2008; Keaveney, 1995; McColl-Kennedy and Smith, 2006; Zeelenberg and Pieters, 2004).

As the preventive action, building up and maintaining service quality are the key activities for customer retention (Zeithaml, Berry and Parasuraman, 1996). As the corrective action, service recovery activity (Gronroos, 1988) is the key resolutions in recovering customer bad service experience (e.g., Crisafulli and Singh, 2016; Lastner et al., 2016). The successful service recovery can lead to the positive outcomes following the flaw service encounter, for example, satisfaction, repurchasing, and positive word-of-mouth (Gelbrich, 2010; Hennig-Thurau et al., 2004; Matos et al., 2011). Above all, service recovery will not be provided without service failure recognition.

\subsection{Customer complaint}

Customer response to service failure is explained by consumer complaint behavior. Singh (1988) suggested three types of customer response to bad consumption experiences, namely, private response, 
third-party response, and voice response. Private response involves customers' actions with party in their own network who did not involve in the service problem e.g., negative word-of-mouth communication. Third-party response is an action that the customers interact with the party out of personal network and did not involve in the service transaction e.g., consumer protection organization. Voice response concerns either to voice or to not voice to the service provider.

Based on the service recovery literature, voice response to the service provider (customer complaint) is the only response from customer that provides service provider a chance to take a service recovery action (Tax and Brown, 2012). Given that the firm may not recognize service failure by itself, customer complaint is the only source that directs to service recovery activity.

However, consumer complaint research suggested that most of the customers who encountered service failure do not report to the service provider. Two thirds of the dissatisfied customers do not complain to the service organization (Stephens and Gwinner, 1998). More recently, it has been reported that up to nine tenth of the dissatisfied customers do not raise their complaint to the firms (Tax and Brown, 2012). As a result, it can be seen that most of service recovery research draw the research model by linking service recovery with consumer complaint behavior (e.g., Kim, Wang and Mattila, 2010; Ro and Mattila, 2015; Voorhees, Brady and Horowitz, 2006). It would appear that dissatisfied customers who do not complain will not receive service recovery and may exhibit other types of negative response, which are harmful for developing sustainable relationships.

\subsection{Complaint invitation}

To address the non-complaint issue, the present study proposes a tool, complaint invitation, to take responsibility in turning the unrecognized service failure into a recognized one. Complaint invitation serves as a procedure to identify service failure that might happen; and as a result, the service provider can provide a proper service recovery actions.

Accordingly, this study categorizes customer complaint into two types: customer-self complaint and invited complaint. First, the customer-self complaint is a normal customer complaint, which is generally voiced by dissatisied customers. And second, the invited complaint is a customer complaint, which is voiced following the complaint invitaion process.

\subsection{Perceived justice}

Effectiveness of service recovery is generally measured by customer satisfaction and behavioral responses through the mediation of perceived justice of service recovery (e.g., del Río-Lanza, VázquezCasielles and Díaz-Martín, 2009; Fang, Luo and Jiang, 2013; Kau and Loh, 2006; Matos et al., 2011; Ok, 2004; Park, 2012; Patterson, Cowley and Prasongsukarn, 2006).

Theory of perceived justice explains individuals' reactions to different conflict situations (Blodgett, Hill and Tax, 1997). It has largely been used as a theoretical base to understand consumer behavior in service failure and service recovery contexts (Chebat and Slusarczyk, 2005; Ha and Jang, 2009; McCollough and Bharadwaj, 1992; Patterson, Cowley and Prasongsukarn, 2006; Smith, Bolton and Wagner, 1999). Justice perception can explain customers' evaluation of service recovery (Blodgett, Hill and Tax, 1997; McColl-Kennedy and Sparks, 2003); for example, if customers believe they were treated fairly, their level of satisfaction and future loyalty will be accordingly high (McColl-Kennedy and Sparks, 2003). Justice perception includes three dimensions, namely, distributive, procedural, and interactional justice (McColl-Kennedy and Sparks, 2003).

Distributive justice postulates that individuals would evaluate the satisfactoriness of an exchange in terms of its fairness as defined by the amount of resources (inputs) given and the appropriateness of the gain received (reward or outcome) (McCollough, 1995). Tax, Brown and Chandrashekaran (1998) suggested three elements of distributive justice, including equity, equality, and need. Equity is defined as "provision of outcomes proportional to inputs to an exchange" (Tax, Brown and Chandrashekaran, 1998). Equality is "equal outcomes regardless of contributions to an exchange," whereas need refers to "outcome based on requirements regardless of contributions" (Tax, Brown and Chandrashekaran, 1998).

Perceived procedural justice refers to perceived fairness of procedure, policies, and criteria in providing resolution following service breakdown (Maxham III and Netemeyer, 2002; McCollough, 1995). The fair procedure could be perceived through accessibility, speed, process control, flexibility, and delay 
of methods the service providers perform during service recovery process (del Río-Lanza, VázquezCasielles and Díaz-Martín, 2009). According to Tax, Brown and Chandrashekaran (1998), accessibility means "ease of engaging a process," speed is the "perceived amount of time taken to complete procedure," process control refers to "freedom to communicate views on decision process," while flexibility refers to "adaptability of procedures to reflect individual circumstances". Delay refers to how prompt was the response to solve a problem.

Perceived interactional justice involves interpersonal treatments individual perceives during the problem-solving process (Blodgett, Hill and Tax, 1997). Perceived interactional justice involves manners and interactions where the service provider interacts with customers during a service recovery encounter (McColl-Kennedy and Sparks, 2003). Tax, Brown and Chandrashekaran (1998) proposed five elements of interactional justice, which include "causal account", "honesty", "politeness", "effort" and "empathy. This study is supported by del Río-Lanza, Vázquez-Casielles and Díaz-Martín (2009) examination of the cellular-telephone sector. They revealed that manners and interactions that affect interactional justice include empathy, courtesy, sensitivity, treatment, and employee effort during the service recovery process (del Río-Lanza, Vázquez-Casielles and Díaz-Martín, 2009).

\subsection{Customer satisfaction}

Customer satisfaction has been acknowledged as the key indicator of successful service recovery (e.g., Balaji, Roy and Quazi, 2017; Cheung and To, 2017; Petzer, De Meyer-Heydenrych and Svensson, 2017; Smith, Bolton and Wagner, 1999; Sparks and McColl-Kennedy, 2001; Tektas, 2017). Previous research conceptualized customer satisfaction into two types, namely, satisfaction with service transaction and cumulative satisfaction (Johnson, Anderson and Fornell, 1995; Johnson et al., 2001). VázquezCasielles, Suárez Álvarez and Díaz Martín (2010) described transaction-specific satisfaction as an evaluation of the current service encounter or service recovery. Cumulative satisfaction is the overall satisfaction from all transactions and other experiences; therefore, it reflects the firms' previous and current performance. These two concepts of customer satisfaction are complementary rather than competitive (Johnson et al., 2001).

\subsection{Coping potential}

Coping potential is defined as the individuals' evaluation of their own ability to deal with the situation (Watson and Spence, 2007). Emotions literature identified coping potential as a determinant of helplessness (Lazarus, 1991; Gelbrich, 2010), whereby people in aversive situation with low coping potential have helplessness feeling. For example, a subordinate, who has not been promoted, might feel helplessness because he has low coping potential to alter the situation (Gelbrich, 2010). Based on the literature, it would appear that customers may also assess their ability to cope with the problem in a service failure situation. Thus, this can lead to differences in service recovery evaluations.

\section{Hypothesis development}

\subsection{The effects of complaint situation on perceived justice}

Perceived procedural justice is affected by perception regarding whether service recovery policy and process are fair (Maxham III and Netemeyer, 2002). According to invited complaint situation, the customer is invited to complain about the poor service encounter. Whereas in customer-self complaint situation, the customer identifies service failure and complains to service provider. Goodwin and Ross (1990) documented that consumers are likely to perceive a firm that treats them more fairly when they assume that employees follow a firm's procedure rather than the employee's own decision. To compare these two situations, the current study reasons that the fair policy can be perceived more in the invited complaint situation.

H1a: Customers in invited complaint group exhibit higher perceived procedural justice than customers in customer-self complaint group.

Furthermore, on basis of perceived distributive justice, customers perceive a fair outcome as a result of comparable input and outcome in the exchange (Blodgett, Hill and Tax, 1997). It can be predicted that the less input produces the more perceived distributive justice. Where the invited complaint takes less customer's input involving energy and effort to complain, the customers spend more energy and effort to 
voice complaint without an invitation. The next hypothesis proposes that the customers in different complaint situations have different levels of distributive justice perception.

H1b: Customers in invited complaint group exhibit higher perceived distributive justice than customers in customer-self complaint group.

In terms of interpersonal treatment, the higher perception on the service providers' honesty and empathy can result in higher perceived interactional justice (Blodgett, Hill and Tax, 1997). Contrasting the invited complaint and customer-self complaint in terms of service providers' honesty and empathy, this study argues that the customers can recognize the firm's honesty and empathy more clearly when the firm invited them to complain about the dissatisfaction. This leads to the next hypothesis.

H1c: Customers in invited complaint group exhibit higher perceived interactional justice than customers in customer-self complaint group.

\subsection{The effects of complaint situation on customer satisfaction}

In service recovery context, Stauss (2002) defined complaint satisfaction as the complainers' satisfaction with the firms' response to their complaint. Previous literature suggested that complaint has no main effect on satisfaction. However, under the voice condition with neutral stance of the firms, a firm's concern makes a difference in satisfaction (Sparks and McColl-Kennedy, 2001).

The interaction between customer complaint and the firms' concerns in McColl-Kennedy, Sparks and Nguyen's study is consistent with the invited complaint process in which service provider shows concerns on the potential problem (2011). On the contrary, in the customer-self complaint situation, customer may perceive less firm's concern as the firm shows less concerns on the problem. Taking together, the current study proposes the following hypothesis.

H2: Customers in invited complaint group exhibit higher satisfaction than customers in customer-self complaint group.

\subsection{The moderating effects of coping potential}

Coping potential explains people's assessment on their capability to overcome an aversive circumstance (Lazarus, 1991). Drawn from Lazarus's conclusion, in a service failure context, a low coping potential refers to low perceived ability to deal with the service problem (1991). Therefore, when customers are invited to complain, the low coping potential should interpret service recovery actions more positively than the high coping potential. Based on the discussion, the following hypotheses are proposed.

H3a: The effects of invited complaint on perceived procedural justice will be higher for low coping potential customers than high coping potential customers.

H3b: The effects of invited complaint on perceived distributive justice will be higher for low coping potential customers than high coping potential customers.

H3c: The effects of invited complaint on perceived interactional justice will be higher for low coping potential customers than high coping potential customers.

H3d: The effects of invited complaint on satisfaction will be higher for low coping potential customers than high coping potential customers.

\section{Research methodology}

\subsection{Research design}

A scenario-based experiment was conducted in a bank service setting. Using scenario-based approach to test research hypotheses is consistent with previous studies on service failure and service recovery (e.g., Hazée, Van Vaerenbergh and Armirotto, 2017; Xu, et al., 2014). Smith, Bolton and Wagner (1999) suggested that the scenario-based experiment can facilitate the representative service failure and recovery situations while reducing some limitations of the retrospective self-report approach, e.g., memory lapses and justification tendencies. 
This study utilizes a 2 (complaint situation: customer-self complaint vs. invited complaint) $x 2$ (coping potential: high vs. low) between-subject design. The complaint situation was manipulated by the experiment. Coping potential was measured and divided into two subgroups using the median split.

\subsection{Scenario development}

The scenarios were developed following procedure suggested by McColl-Kennedy, Sparks and Nguyen (2011). A service failure scenario involves an unintentional problem made by the frontline staff. After the customer noticed service failure, the bank addressed the mistake based on two different complaint scenarios, namely, customer-self complaint and invited complaint. In the customer-selfcomplaint scenario, the customer complained to the staff. In the invited complaint scenario, the customer complained when the staff checked customer satisfaction following the service delivery and encouraged the customer to complain if not satisfied. The same service recovery was provided in both complaint scenarios.

\subsection{Sample and procedure}

169 students of undergraduate programs at two universities in Thailand participated in the experiment. The sample consisted of $43 \%$ male, aged 20-25 year. Among them, 100\% were regular customers of the banks and $52 \%$ had a service failure experience similar to the service failure scenario.

Data collection was conducted in the classroom. The participants were firstly greeted by the experimenters. They were then randomly assigned to one of the two complaint scenarios. Next, they were instructed to read a scenario and imagine that they were a customer in the scenario and respond to the questions that followed.

\subsection{Measurements}

Three dimensions of perceived justice and satisfaction measurement scales were adopted from Maxham III and Netemeyer (2002). The measurement items of coping potential were adopted from Gelbrich (2010). Since all measurement scales were in English, the collaborative translation technique was employed to reassure the conceptual equivalence as suggested by Douglas and Craig (2007).

The complaint conditions were manipulated by the experiment. The manipulation and realism of the scenario were checked by asking three manipulation check questions and one realism check question. All questions were measured using seven-point rating scales.

\section{Results}

\subsection{Manipulation and realism check results}

Manipulation and realism check results indicated that the participants perceive complaint conditions correctly. All three manipulation check items demonstrated that participants in invited complaint group rate significantly higher score than participants in customer-self complaint group $(p<0.001)$. The realism check item showed mean score greater than 5 on the seven-point scale, $(M=5.45$, $S D=0.05, p<0.001)$.

\subsection{MANOVA results}

The MANOVA results demonstrated the significant interaction effects between complaint situation and coping potential on dependent variables $(F(4,162)=2.59, p<0.05)$. The tests of between subject effects revealed significant interaction effects on perceived interactional justice, $F(1,165)=7.41, p<0.05$. Significant interaction effects on satisfaction were also found, $F(1,165)=4.71, p<0.05$. However, the interaction between complaint situations and coping potential did not significantly affect perceived procedural justice and distributive justice. Figure 1 and Figure 2 display interaction effects between complaint type and coping potential on perceived interactional justice and satisfaction respectively. 


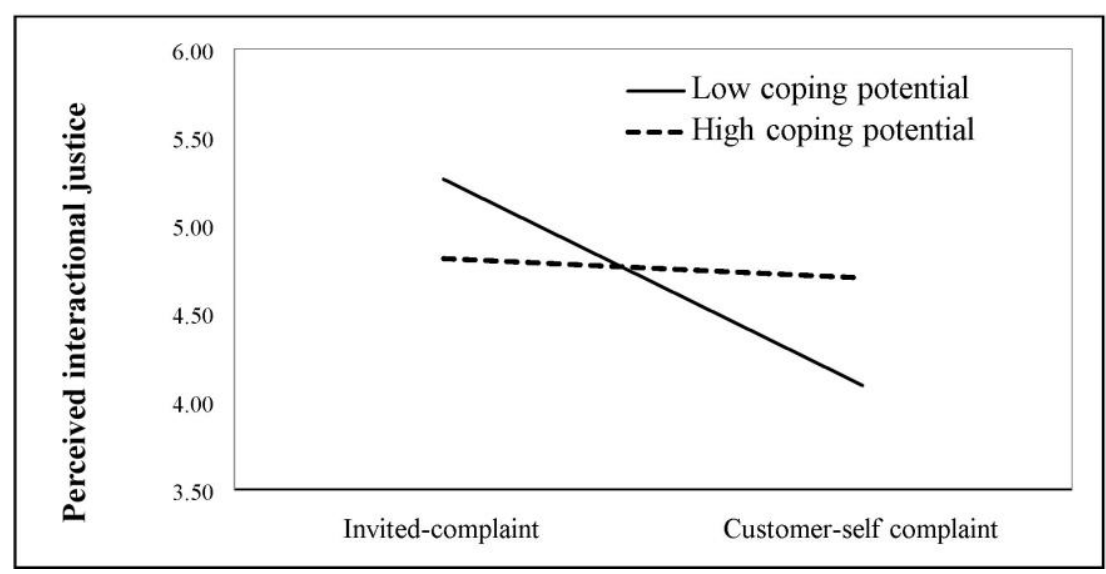

Figure 1: The interaction effect of complaint situation and coping potential on perceived interactional justice

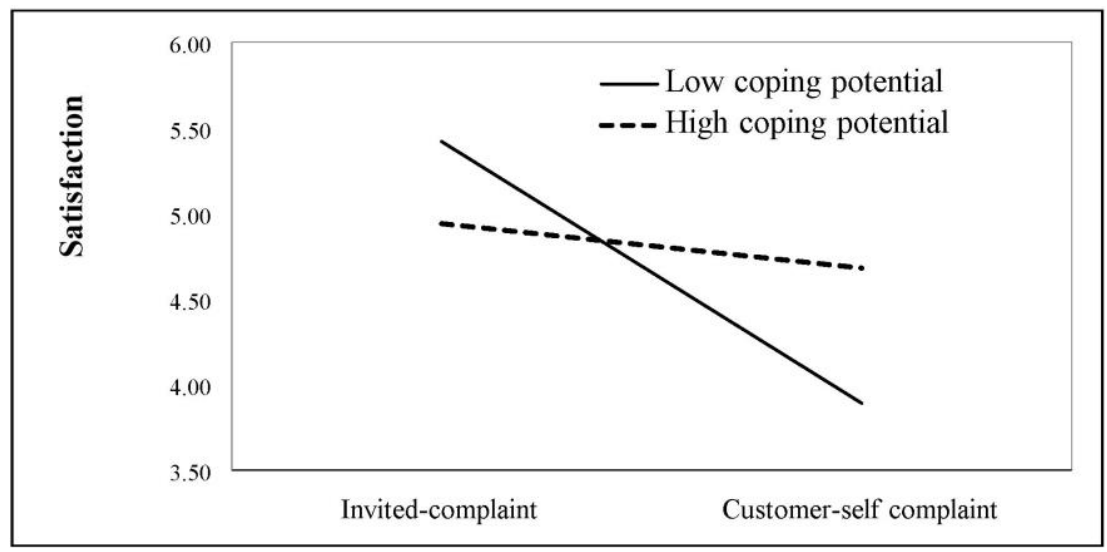

Figure 2: The interaction effect of complaint situation and coping potential on customer satisfaction

\subsubsection{Perceived justice}

The tests of main effects showed that perceived procedural justice $\left(M_{\text {invited complaint }}=5.15, S D=0.12\right.$, $\left.M_{\text {customer-self complaint }}=4.46, S D=0.12, p<0.001\right)$, perceived distributive justice $\left(M_{\text {invited complaint }}=5.16, S D=\right.$ $\left.0.12, M_{\text {customer-self complaint }}=4.56, S D=0.12, p<0.001\right)$, and perceived interactional $\left(M_{\text {invited complaint }}=5.15, S D=\right.$ $0.11, M_{\text {customer-self complaint }}=4.39, S D=0.11, p<0.001$ ) are significantly affected by complaint situations. Thus, $\mathrm{H} 1 \mathrm{a}, \mathrm{H} 1 \mathrm{~b}$ and $\mathrm{H} 1 \mathrm{c}$ are supported.

The planned contrasts indicated that in the invited complaint situation, participants with low coping potential score significantly higher in perceived interactional justice $\left(M_{\text {low coping potential }}=5.26, S D=\right.$ $0.16, M_{\text {high coping potential }}=4.81, S D=0.15, p<0.05$ ). However, this effect is insignificant for perceived procedural justice $\left(M_{\text {low coping potential }}=5.08, S D=0.17, M_{\text {high coping potential }}=5.217, S D=0.16, p>0.05\right)$ and distributive justice $\left.M_{\text {low coping potential }}=5.05, S D=0.17, M_{\text {high coping potential }}=5.26, S D=0.16, p>0.05\right)$. The results provide support for $\mathrm{H} 3 \mathrm{c}$, but not for $\mathrm{H} 3 \mathrm{a}$ and $\mathrm{H} 3 \mathrm{~b}$.

\subsubsection{Customer satisfaction}

The MANOVA tests indicated that satisfaction is significantly affected by complaint situation $\left(M_{\text {invited complaint }}=4.875, S D=0.115, M_{\text {customer-self complaint }}=4.28, S D=0.11, p<0.001\right)$. This provides support for $\mathrm{H} 2$.

In addition, the results of a planned contrast showed that participants in the invited complaint situation with low coping potential score satisfaction significantly different from the participants with 
high coping potential $\left(M_{\text {low coping potential }}=5.42, S D=0.16, M_{\text {high coping potential }}=4.94, S D=0.15, p<0.05\right)$. Therefore, H3d is supported.

\section{Discussions and conclusions}

This research extends the service recovery framework by establishing a new perspective on customer complaint as a service organization's accountability in dealing with a service problem to promote business sustainability. Following the Goal 16 of SDGs, this study proposes a new concept (invited complaint) to promote effective, accountable and transparent institutions at all levels in the service failure context. While research on customer complaint has consistently reported that most customers with bad service experiences do not complain to service providers (e.g., Smith, Bolton and Wagner, 1999; Tax and Brown, 2012), inviting customers to complain represents the firms' responsibility to turn unrecognized service failure into the recognized one. With an implementation of complaint invitation process, the unhappy customers would be given an opportunity to complain that leads to an appropriate service recovery and results in higher perceived justice and satisfaction.

As the indicator of the Goal 16 of SDGs is the people satisfaction with service experiences (United Nations, 2015), the results of this study have ensured that the invited complaint concept incorporates sustainability features that increase positive service experiences over the customer-self complaint situation. In addition, the positive effects of the invited complaint on service recovery evaluations are consistent with recent research in service recovery, suggesting that customers perceive co-creation recovery more positively when they are asked by the firm to participate in the co-creation recovery (Xu et al., 2014).

This study also contributes to a better understanding of managerial practice related to the challenge of service business sustainability. As part of sustainable development, sustainability marketing is achieved through building and maintaining a firm-customer relationship (Belz, 2006; Peattie and Belz, 2010). In an analogous fashion, the findings of this research demonstrate that following up customer satisfaction after service encounter is one of the key steps in building business sustainability. More specifically, this research suggests service providers to ensure that the customers satisfy with the service and invite them to complain the dissatisfaction. By doing this, the customers will perceive higher fairness and will be more satisfied with service recovery.

Moreover, invited complaint could be used as a strategy to develop sustainable service design for customers (Chowdhury and Quaddus, 2016). By inviting customers to complain, service providers can monitor and collect customer feedbacks as well as integrate their suggestions to improve the service and to ensure effective service delivery. In addition, the key insight derived from the investigation of the moderating effects of coping potential on the relationships between complaint situations and service recovery evaluations is that, when customers perceive low potential to cope with situations, they would perceive higher helplessness (Gelbrich, 2010). Therefore, a complaint invitation can produce more interactional justice perception and satisfaction for customers with low coping potential.

\section{Limitations and direction for future research}

While this study has made significant contributions to service recovery literature, some limitations provide ideas for future research. First, this study was conducted using a scenario-based experiment to elicit customer response to the experimental conditions. Although the experimental approach provides internal validity, it lacks external validity. The future study may consider using actual service failure experiences to test hypotheses.

Second, undergraduate students were used as the subjects in this study. While the students were screened for experience in using financial services consistent with the scenario, they may not be representative of the wider population. To increase the representative sample, future studies may use non-student subjects to enhance generalizability.

Third, this research was conducted in only one service context, namely, a retail banking service. Therefore, the results may not be applicable to other retail service industries. The future studies may consider testing the effects of complaint situations in other industries, for example, restaurants, hotels, and airlines. 
Fourth, this research has addressed the effects of complaint situation on perceived justice and customer satisfaction. While the experiment provided a better understanding of customer responses to the complaint situations, the current study did not investigate how complaint situations affect other consumer behaviors. Future research could examine the effects of complaint situations on behavioral outcomes; for instance, repurchase intention, word-of-mouth communication, and switching service provider.

Furthermore, with regard to the implications for researchers, the findings of this study provide potential lines for future research. The favorable effects of complaint invitation on perceived service recovery performance leave the question of how emotions involve in this relationship. Research on customer negative emotions in service failure context suggested that the negative emotions triggered by bad service experience have negative bias on perceived justice toward complaint handling (Tektas, 2017). Therefore, the further study on complaint handling should test how the effects of complaint invitation on post-complaint behavior vary across different degrees of negative emotions and different specific negative emotions.

Additionally, this research demonstrates that the invited complaint results in higher perceived justice and satisfaction than the customer-self complaint. To better understand the effects of complaint situation on customer post-complaint behavior, the set of complaint aspects should be refined and enriched. Hence, the further research should explore if other aspects of complaint (for example, immediate or delayed complaint) lead to different customer evaluations of service recovery.

\section{References}

Balaji, M.S., Roy, S.K. and Quazi, A. (2017). Customers' Emotion Regulation Strategies in Service Failure Encounters. European Journal of Marketing, 51(5/6), pp. 960-982.

Belz, F.M. (2006). Marketing in the 21st Century. Business Strategy and the Environment, 15(3), pp. 139-144.

Berry, L.L. (2016). Revisiting" Big Ideas in Services Marketing" 30 Years Later. Journal of Services Marketing, 30(1), pp. 36.

Blodgett, J.G., Hill, D.J. and Tax, S.S. (1997). The Effects of Distributive, Procedural, and Interactional Justice on Postcomplaint Behavior. Journal of Retailing, 73(2), pp. 185-210.

Chebat, J.C. and Slusarczyk, W. (2005). How Emotions Mediate the Effects of Perceived Justice on Loyalty in Service Recovery Situations: An Empirical Study. Journal of Business Research, 58(5), pp. 664-673.

Chen, W. and Lee, H.C. (2018). How to Explain Service Failure? Impacts of Justifications. Service Business, 12(2), pp. 331-356.

Cheung, M.F. and To, W.M. (2017). The Effect of Organizational Responses to Service Failures on Customer Satisfaction Perception. Service Business, 11 (4), pp. 767-784

Chowdhury, M.M.H. and Quaddus, M.A. (2016). A Multi-Phased Qfd Based Optimization Approach to Sustainable Service Design. International Journal of Production Economics, 171, pp. 165-178.

Crisafulli, B. and Singh, J. (2016). Service Guarantee as a Recovery Strategy: The Impact of Guarantee Terms on Perceived Justice and Firm Motives. Journal of Service Management, 27(2), pp. 117-143.

del Río-Lanza, A.B., Vázquez-Casielles, R. and Díaz-Martín, A.M. (2009). Satisfaction with Service Recovery: Perceived Justice and Emotional Responses. Journal of Business Research, 62(8), pp. 775-781.

Douglas, S.P. and Craig, C.S. (2007). Collaborative and Iterative Translation: An Alternative Approach to Back Translation. Journal of International Marketing, 15(1), pp. 30-43.

Fang, Z., Luo, X. and Jiang, M. (2013). Quantifying the Dynamic Effects of Service Recovery on Customer Satisfaction Evidence from Chinese Mobile Phone Markets. Journal of Service Research, 16(3), pp. 341-355.

Gelbrich, K. (2010). Anger, Frustration, and Helplessness after Service Failure: Coping Strategies and Effective Informational Support. Journal of the Academy of Marketing Science, 38(5), pp. 567-585.

Goodwin, C. and Ross, I. (1990). Consumer Evaluations of Responses to Complaints: What's Fair and Why. Journal of Consumer Marketing, 7(2), pp. 39-47.

Gronroos, C. (1998). Service Quality: The Six Criteria of Good Perceived Service Quality. Review of Business, 9(3), pp. 10-13.

Ha, J. and Jang, S.S. (2009). Perceived Justice in Service Recovery and Behavioral Intentions: The Role of Relationship Quality. International Journal of Hospitality Management, 28(3), pp. 319-327.

Hart, C.W., Heskett, J.L. and Sasser Jr, W.E. (1989). The Profitable Art of Service Recovery. Harvard Business Review, 68(4), pp. 148-156.

Hazée, S., Van Vaerenbergh, Y. and Armirotto, V. (2017). Co-Creating Service Recovery after Service Failure: The Role of Brand Equity. Journal of Business Research, 74, pp. 101-109. 
Hennig-Thurau, T., Gwinner, K.P., Walsh, G. and Gremler, D.D. (2004). Electronic Word-of-Mouth Via ConsumerOpinion Platforms: What Motivates Consumers to Articulate Themselves on the Internet? Journal of Interactive Marketing, 18(1), pp. 38-52.

Johnson, M.D., Anderson, E.W. and Fornell, C. (1995). Rational and Adaptive Performance Expectations in a Customer Satisfaction Framework. Journal of Consumer Research, 21(4), pp. 695-707.

Johnson, M.D., Gustafsson, A., Andreassen, T.W., Lervik, L. and Cha, J. (2001). The Evolution and Future of National Customer Satisfaction Index Models. Journal of economic Psychology, 22(2), pp, 217-245.

Kalamas, M., Laroche, M. and Makdessian, L. (2008). Reaching the Boiling Point: Consumers' Negative Affective Reactions to Firm-Attributed Service Failures. Journal of Business Research, 61(8), pp. 813-824.

Kau, A.K. and Loh, E.W.Y. (2006). The Effects of Service Recovery on Consumer Satisfaction: A Comparison between Complainants and Non-Complainants. Journal of Services Marketing, 20(2), pp. 101-111.

Keaveney, S.M. (1995). Customer Switching Behavior in Service Industries: An Exploratory Study. The Journal of Marketing, pp. 71-82.

Kim, M.G., Wang, C. and Mattila, A.S. (2010). The Relationship between Consumer Complaining Behavior and Service Recovery: An Integrative Review. International Journal of Contemporary Hospitality Management, 22(7), pp. 975-991.

Kumar, V., Aksoy, L., Donkers, B., Venkatesan, R., Wiesel, T. and Tillmanns, S. (2010). Undervalued or Overvalued Customers: Capturing Total Customer Engagement Value. Journal of Service Research, 13(3), pp. $297-310$.

Lastner, M.M., Folse, J.A.G., Mangus, S.M. and Fennell, P. (2016). The Road to Recovery: Overcoming Service Failures Through Positive Emotions. Journal of Business Research, 69(10), 4278-4286.

Lazarus, R.S. (1991). Emotion and Adaptation, Handbook of Personality: Theory and Research. New York: Oxford University Press, pp. 609-637.

Levesque, T.J. and McDougall, G.H. (1996). Customer Dissatisfaction: The Relationship between Types of Problems and Customer Response. Canadian Journal of Administrative Sciences/Revue Canadienne des Sciences de l'Administration, 13(3), pp. 264-276.

Matos, C.A.D., Fernandes, D.V.D.H., Leis, R.P. and Trez, G. (2011). A Cross-Cultural Investigation of Customer Reactions to Service Failure and Recovery. Journal of International Consumer Marketing, 23(3-2), pp. 211-228.

Maxham III, J.G. (2001). Service Recovery's Influence on Consumer Satisfaction, Positive Word-of-Mouth, and Purchase Intentions. Journal of Business Research, 54(1), pp. 11-24.

Maxham III, J.G. and Netemeyer, R.G. (2002). Modeling Customer Perceptions of Complaint Handling over Time: The Effects of Perceived Justice on Satisfaction and Intent. Journal of Retailing, 78(4), pp. 239-252.

McColl-Kennedy, J.R. and Smith, A.K. (2006). Chapter 10 Customer Emotions in Service Failure and Recovery Encounters. Individual and Organizational Perspectives on Emotion Management and Display: Emerald Group Publishing Limited, pp. 237-268.

McColl-Kennedy, J.R. and Sparks, B.A. (2003). Application of Fairness Theory to Service Failures and Service Recovery. Journal of Service Research, 5(3), pp. 251-266.

McColl-Kennedy, J.R., Sparks, B.A. and Nguyen, D.T. (2011). Customer's Angry Voice: Targeting Employees or the Organization? Journal of Business Research, 64(7), pp. 707-713.

McCollough, M.A. (1995). The Recovery Paradox: A Conceptual Model and Empirical Investigation of Customer Satisfaction and Service Quality Attitudes after Service Failure and Recovery. PhD. Texas A\&M University.

McCollough, M.A., Berry, L.L. and Yadav, M.S. (2000). An Empirical Investigation of Customer Satisfaction after Service Failure and Recovery. Journal of Service Research, 3(2), pp. 121-137.

McCollough, M.A. and Bharadwaj, S.G. (1992). The Recovery Paradox: An Examination of Consumer Satisfaction in Relation to Disconfirmation, Service Quality, and Attribution Based Theories. Marketing theory and applications, 119.

Ok, C. (2004). The Effectiveness of Service Recovery and Its Role in Building Long-Term Relationships with Customers in a Restaurant Setting. PhD. Kansas State University.

Park, J. (2012). The Role of Customer Participation in Customer Satisfaction with Service Recovery. PhD. Purdue University.

Patterson, P.G., Cowley, E. and Prasongsukarn, K. (2006). Service Failure Recovery: The Moderating Impact of Individual-Level Cultural Value Orientation on Perceptions of Justice. International Journal of Research in Marketing, 23(3), pp. 263-277.

Peattie, K. and Belz, F.M. (2010). Sustainability Marketing - an Innovative Conception of Marketing. Marketing Review St. Gallen, 27(5), pp. 8-15.

Petzer, D.J., De Meyer-Heydenrych, C.F. and Svensson, G. (2017). Perceived Justice, Service Satisfaction and Behavior Intentions Following Service Recovery Efforts in a South African Retail Banking Context. International Journal of Bank Marketing, 35(2), pp. 241-253.

Rakic, B. and Rakic, M. (2015). Holistic Management of Marketing Sustainability in the Process of Sustainable Development. Environmental Engineering E Management Journal, 14 (4), pp. 887-900. 
Ro, H. and Mattila, A.S. (2015). Silent Voices: Nonbehavioral Reactions to Service Failures. Services Marketing Quarterly, 36(2), pp. 95-111.

Singh, J. (1988). Consumer Complaint Intentions and Behavior: Definitional and Taxonomical Issues. The Journal of Marketing, 52(1), pp. 93-107.

Smith, A.K., Bolton, R.N. and Wagner, J. (1999). A Model of Customer Satisfaction with Service Encounters Involving Failure and Recovery. Journal of Marketing Research, 36(3), pp. 356-372.

Sparks, B.A. and McColl-Kennedy, J.R. (2001). Justice Strategy Options for Increased Customer Satisfaction in a Services Recovery Setting. Journal of Business Research, 54(3), pp. 209-218.

Stauss, B. (2002). The Dimensions of Complaint Satisfaction: Process and Outcome Complaint Satisfaction Versus Cold Fact and Warm Act Complaint Satisfaction. Managing Service Quality: An International Journal, 12(3), pp. 173-183.

Stephens, N. and Gwinner, K.P. (1998). Why Don't Some People Complain? A Cognitive-Emotive Process Model of Consumer Complaint Behavior. Journal of the Academy of Marketing science, 26(3), pp. 172-189.

Tax, S.S. and Brown, S.W. (2012). Recovering and Learning from Service Failure. Sloan Management, 40(1), pp. 75-89.

Tax, S.S., Brown, S.W. and Chandrashekaran, M. (1998). Customer Evaluations of Service Complaint Experiences: Implications for Relationship Marketing. The Journal of Marketing, 62(2), pp. 60-76.

Tektas, O.O. (2017). Perceived Justice and Post-Recovery Satisfaction in Banking Service Failures: Do Commitment Types Matter? Service Business, 11(4), pp. 851-870.

United Nations. (2015). Transforming our world: The 2030 agenda for sustainable development. ' Available at: https://sustainabledevelopment.un.org/content/documents/21252030\%20Agenda\% 20for\%20Sustainable\%20Development\%20web.pdf [Accessed 3 Jun. 2016].

Vázquez-Casielles, R., Suárez Álvarez, L. and Díaz Martín, A.M. (2010). Perceived Justice of Service Recovery Strategies: Impact on Customer Satisfaction and Quality Relationship. Psychology E Marketing, 27(5), pp. 487509.

Voorhees, C.M., Brady, M.K. and Horowitz, D.M. (2006). A Voice from the Silent Masses: An Exploratory and Comparative Analysis of Noncomplainers. Journal of the Academy of Marketing Science, 34(4), pp. 514-527.

Watson, L. and Spence, M.T. (2007). Causes and Consequences of Emotions on Consumer Behavior: A Review and Integrative Cognitive Appraisal Theory. European Journal of Marketing, 41(5/6), pp. 487-511.

Xu, Y., Marshall, R., Edvardsson, B. and Tronvoll, B. (2014). Show You Care: Initiating Co-Creation in Service Recovery. Journal of Service Management, 25(3), pp. 369-387.

Yilmaz, V., Ari, E. and Gürbüz, H. (2018). Investigating the Relationship between Service Quality Dimensions, Customer Satisfaction and Loyalty in Turkish Banking Sector: An Application of Structural Equation Model. International Journal of Bank Marketing, 36(3), pp. 423-440.

Zeelenberg, M. and Pieters, R. (2004). Beyond Valence in Customer Dissatisfaction: A Review and New Findings on Behavioral Responses to Regret and Disappointment in Failed Services. Journal of Business Research, 57(4), pp. 445-455.

Zeithaml, V.A., Berry, L.L. and Parasuraman, A. (1996). The Behavioral Consequences of Service Quality. The Journal of Marketing, 60(2), pp. 31-46. 